- ANL/OTEC-BCM-010

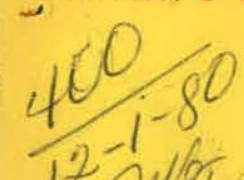

Dr. 2053

ANL/OTEC-BCM-010

\title{
ANTIFOULING MARINE CONCRETE
}

Harold P. Vind and Charles W. Mathews
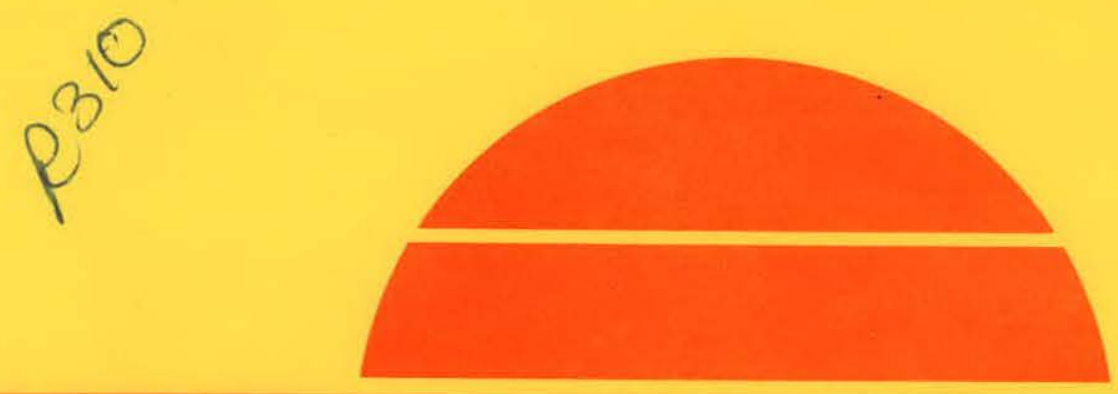

\section{MASTER}

Argonne National Laboratory

9700 South Cass Avenue

Argonne, Illinois 60439
Prepared for the

U. S. Department of Energy

Division of Central Solar Technology under Contract W-31-109-Eng-38 


\section{DISCLAIMER}

This report was prepared as an account of work sponsored by an agency of the United States Government. Neither the United States Government nor any agency Thereof, nor any of their employees, makes any warranty, express or implied, or assumes any legal liability or responsibility for the accuracy, completeness, or usefulness of any information, apparatus, product, or process disclosed, or represents that its use would not infringe privately owned rights. Reference herein to any specific commercial product, process, or service by trade name, trademark, manufacturer, or otherwise does not necessarily constitute or imply its endorsement, recommendation, or favoring by the United States Government or any agency thereof. The views and opinions of authors expressed herein do not necessarily state or reflect those of the United States Government or any agency thereof. 


\section{DISCLAIMER}

Portions of this document may be illegible in electronic image products. Images are produced from the best available original document. 
The facilities of Argonne National Laboratory are owned by the United States Government. Under the terms of a contract (W-31-109-Eng-38) among the U. S. Department of Energy, Argonne Universities Association and The University of Chicago, the University employs the staff and operates the Laboratory in accordance with policies and programs formulated, approved and reviewed by the Association.

\title{
MEMBERS OF ARGONNE UNIVERSITIES ASSOCIATION
}

The University of Arizona

Carnegie-Mellon University

Case Western Reserve University

The University of Chicago

University of Cincinnati

Illinois Institute of Technology

University of Illinois

Indiana University

The University of Iowa

Iowa State University
The University of Kansas

Kansas State University

Loyola University of Chicago

Marquette University

The University of Michigan

Michigan State University

University of Minnesota

University of Missouri

Northwestern University

University of Notre Dame
The Ohio State University

Ohio University

The Pennsylvania State University

Purdue University

Saint Louis University

Southern Illinois University

The University of Texas at Austin

Washington University

Wayne State University

The University of Wisconsin-Madison

\begin{abstract}
-NOTICE
This report was prepared as an account of work sponsored by an agency of the United States Government. Neither the United States Government or any agency thereof, nor any of their employees, make any warranty, express or implied, or assume any legal liability or responsibility for the accuracy, completeness, or usefulness of any information, apparatus, product, or process disclosed, or represent that its use would not infringe privately owned rights. Reference herein to any specific commercial product, process, or service by trade name, mark, manufacturer, or otherwise, does not necessarily constitute or imply its endorsement, recommendation, or favoring by the United States Government or any agency thereof. The views and opinions of authors expressed herein do not necessarily state or reflect those of the United States Government or any agency thereof.
\end{abstract}

Printed in the United States of America

Available from

National Technical Information Service

U. S. Department of Commerce

5285 Port Royal Road

Springfield, VA 22161

NTIS price codes

Printed copy: A03

Microfiche copy: A01 


\section{ARGONNE NATIONAL LABORATORY \\ 9700 South Cass Avenue \\ Argonne, Illinois 60439}

ANTIFOULING MARINE CONCRETE

by

Harold P. Vind and Charles W. Mathews

Civil Engineering Laboratory Naval Construction Battalion Center Port Hueneme, California 93043

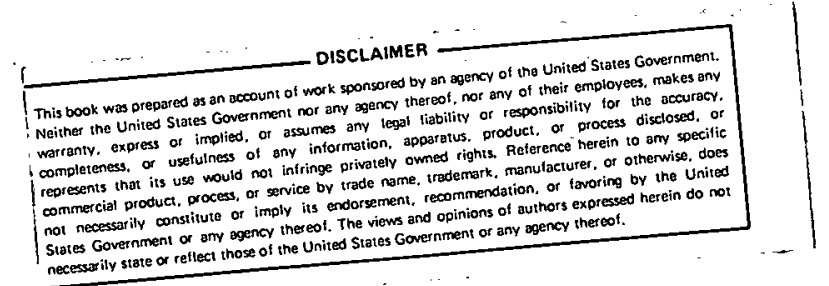

July 1980

Prepared for

Argonne National Laboratory

Under Interagency Agreement No. EG-77-A-29-1104 
CONTENTS

Page

EXECUTIVE SUMMARY . . . . . . . . . . . . . . . . . . . 1

ABSTRACT . . . . . . . . . . . . . . . . . . . . . 3

I. INTRODUCTION . . . . . . . . . . . . . . . . . . . 4

II. EXPERIMENTAL PROCEDURES . . . . . . . . . . . ........ . 5

A. PREPARATION OF TREATED AGGREGATE . . . . . . . . . . . . . 5

B. PREPARATION OF CONCRETE SPECIMENS . . . . . . . . . . . . . 6

C. OCEAN EXPOSURE OF SPECIMENS

D. TEST FOR CORROSION OF REINFORCING RODS . . . . . . . . . . 8

E. BIOTOXICITY TESTS . . . . . . . . . . . . . . . . . . . 8

III. FINDINGS . . . . . . . . . . . . . . . . . . . . . 10

A.. ANTIFOULING PROPERTIES . . . . . . . . . . . . . ...... . 10

B. COMPRESSIVE STRENGTH . . . . . . . . . . . . . . . . . . . . . 10

C. EFFECT OF ADDITIVES ON CORROSION OF SIMULATED

REINFORCING ROD . . . . . . . . . . . . . . . . . . 11

D. BIOTOXICITY . . . . . . . . . . . . . . . . 12

IV. DISCUSSION . . . . . . . . . . . . . . . . . . 14

A. COST OF MATERIALS . . . . . . . . . . . . . . . . . . . 14

B. EXPOSURE SITES AND METHODS . . . . . . . . . . . . . . . 15

C. OBJECTIVE RATINGS . . . . . . . . . . . . . . . . . . . . 15

D. PERSISTENCE OF ORGANOTINS . . . . . . . . . . . . . . . . 15

V. SUMMARY AND CONCLUSIONS . . . ................ . . 17

VI. RECOMMENDATIONS . . . . ................. . . . . 19

ACKNOWLEDGMENTS . . . . . . . . . . . . . . . . . . . . . . 20

REFERENCES . . : . . . . . . . . . . . . . . . . . . . . 21 
Floating structures in the ocean soon become the residence of a vast number of marine plants and animals, loosely termed fouling organisms. The proposed Ocean Thermal Energy Conversion (OTEC) plant will have a concrete hull and cold water gathering pipe, both of which are potential homes of such marine fouling organisms. The objective of this work is to prepare a concrete which will resist or prevent the attachment of members of the fouling community.

To accomplish this, three methods of preparation of antifouling concrete were investigated. In the first, liquid toxicants were impregnated into a porous expanded shale aggregate, and concrete was prepared with it in an otherwise normal manner. Alternatively, dry toxicants were added directly to the concrete mix. The toxicants employed as additives in this investigation were organotin compounds, creosote, cuprous oxide, and a chlorinated organic insecticide. They were evaluated alone and/or in certain combinations. The third method involved the application of a coating to otherwise untreated concrete. Two antifouling coating systems containing organotin toxicants were investigated.

All of the materials investigated were incorporated into or were applied to 3-inch-diameter by 6-inch-long concrete cylinders. The test cylinders were then exposed in the ocean at Port Hueneme, CA, and Key Biscayne, FL. The cylindrical shape was chosen so that compressive strength determinations could be made according to American Society for Testing and Materials standards. The antifouling properties of candidate concretes were measured by periodically weighing the adhering fouling organisms.

Two systems employing toxicants as additives to concrete were found to have significant antifouling properties. The first of these employed porous aggregate impregnated with a mixture of bis-(tri-n-butyltin) oxide (TBTO) and creosote. The second system employed triphenyltin hydroxide (TPTH), cuprous oxide, and methoxychlor, all of which are added to the concrete mix as dry powders. Both of the coating systems evaluated exhibited good antifouling properties. One consisted of a liquid organotin-polysiloxane coating that is brush-applied and allowed to cure by reaction with moisture in the air. The second coating consisted of a sheet of rubber impregnated with TBTO which was secured to the concrete by an adhesive.

Compressive strength tests of concrete that contained antifoulant chemicals indicated that an antifouling concrete of sufficient strength could be prepared. Investigations into the effect of the antifouling additives on the corrosion of reinforcing rods were performed. These tests indicated that those additives which proved efficacious also retarded the corrosion of steel reinforcement. Biotoxicity. tests revealed that the toxicants were lethal to test organisms in very small doses. Organotin (as TBTO) has been found to remain bound in an organic molecule in concrete for $6 \frac{3}{3}$ years in the ocean. 
The cost of the toxicants employed is significant, and will be a criterion in the selection of an antifouling system. The coating system that utilizes the organotin-polysiloxane polymer is the least expensive, but insufficient data have been obtained to permit an estimation of its useful lifetime. At the coverage rate used in this investigation, the cost of this product was $\$ 0.10 / \mathrm{ft}^{2}$. The TBTO-impregnated rubber is more costly (cost increases with an increase in thickness). A one-inch-thick panel has remained totally fouling free in Biscayne Bay for 7 years, according to the manufacturer, and a 0.5 -inch-thick sheet has an estimated antifouling life of 25 years in tropical waters. An 0.08 -inch-thick sheet of this rubber product plus the adhesives cost $\$ 4.85 / \mathrm{ft} \mathrm{t}^{2}$. The cost of the toxicant-bearing concretes described in this investigation depends upon the thickness applied. Assuming a 0.5-inch layer, the cost of the toxicant in the TBTO-creosote system is $\$ 1.64 / \mathrm{ft}^{2}$. This could be reduced (and perhaps an even better concrete prepared) by decreasing the ratio of TBTO to creosote. The system employing TPTH, cuprous oxide, and methoxychlor carries a toxicant cost of $\$ 2.64 / \mathrm{ft}^{2}$ when applied 0.5 inch thick. Insufficient data are available to make it possible to speculate on whether this cost could be reduced significantly without losing the antifouling properties of the concrete. 


\section{ABSTRACT}

Various toxic agents were evaluated as to their capability to prevent or inhibit the attachment of marine fouling organisms to concrete. Creosote and bis-(tri-n-butyltin) oxide (TBTO) were impregnated into porous aggregate which was used in making concrete. Cuprous oxide, triphenyltin hydroxide (TPTH), and 2-2-bis-(p-methoxyphenyl)-1,1,1-trichloroethane (methoxychlor) were used as dry additives. Two proprietary formulations. were applied as coatings on untreated concrete. Test specimens were exposed at Port Hueneme, CA, and Key Biscayne, FL. The efficacy of toxicants was determined by periodically weighing the adhering fouling organisms. Concrete prepared with an aggregate impregnated with a TBTO/creosote mixture has demonstrated the best antifouling performance of those specimens exposed for more than one year. The two proprietary coatings and the concrete containing methoxychlor, TPTH, and cuprous oxide as dry additives have exhibited good antifouling properties, but they have been exposed for a shorter time. The strength of concrete containing the toxicants was acceptable, and the toxicants did not increase the corrosion rate of reinforcing rods. Organotin compounds were essentially unchanged in concrete specimens exposed $6 \frac{2}{2}$ years in seawater. 


\section{INTRODÚCTION}

For centuries ships were "careened," or laid over on their sides, to remove fouling from their hulls and replace the materials then used as antifoulants. In 1495, the first dry dock was built for Henry VII at Portsmouth, 1 and this method for removal of fouling has today replaced careening. Neither of those methods is presented as a possible way to keep an Ocean Thermal Energy Conversion (OTEC) facility free of fouling; but they are cited to present the difficulty man has encountered over the centuries in ridding his ocean-going vessels of accumulating biomass. A two-year program in antifouling marine concrete studies was sponsored by the Department of Energy at the Civil Engineering Laboratory to investigate antifouling systems for concrete for possible OTEC use.

Growth of marine fouling organisms on a floating structure can add significantly to its weight, thus reducing freeboard. Biomass has been known to accumulate to $251 \mathrm{~b} / \mathrm{ft}^{2}$ on buoys in less than 3 years. ${ }^{2}$ The cold water pipe of an OTEC plant, when fouled, would provide a reservoir of adult organisms ${ }^{3}$ which could discharge eggs or larvae directly onto the heat exchanger surfaces. Adult members of an established fouling community would increase drag, slough off in time, and cause clogging of screens. The increased drag would increase the stresses on the cold water pipe. Broken pieces of calcareous shells of adults carried in cold water intake would present additional problems. Therefore, the Civil Engineering Laboratory (CEL) has undertaken a task to investigate methods of producing concrete that resists the attachment of marine fouling organisms. Such a concrete would be used to form or line the hull and cold water pipe of a proposed OTEC structure.

Ten years ago, Mr. James Muraoka of CEL prepared concrete into which he incorporated toxic chemicals as antifoulants. ${ }^{4,5}$ He was issued a patent for his method of incorporating the oily toxicants into the concrete. ${ }^{6}$ This involved impregnating a porous, expanded shale aggregate with such toxicanțs as bis-(tri-n-butyltin) oxide (TBTO) and creosote. Concrete was then prepared from the treated aggregate, cement, and water. Toxicants other than TBTO and cresote were evaluated. These included pentachlorophenol, quaternary amines, malachite green base, malachite green oxalate, tributyltin fluoride, nicotine, and copper naphthenate. Muraoka concluded, however, that a mixture of creosote and TBTO $(75: 25$ by volume) yielded concrete having the best antifouling properties. 5 Because he was interested primarily in antifouling properties, he didn't use sand in his concrete mix design. As a result, the compressive strength of the product was lower than that of standard concrete. With the advent of concept of OTEC, an antifouling concrete with a higher compressive strength was required. The work described in this report is directed toward that objective. 


\section{EXPERIMENTAL PROCEDURES}

Candidate antifouling concretes were prepared by (1) impregnating porous aggregate with liquid toxicants, (2) adding dry toxicants directly to the dry mix, or ( 3 ) coating otherwise untreated concrete with a material intended to resist fouling. Combinations of the first two of these methods were also investigated. The candidate concretes along with controls were placed in the ocean off the California and Florida coasts, and their ability to resist the attachment of fouling organisms was periodically determined by weighing them and comparing their weights with those of controls.

\section{A. PREPARATION OF TREATED AGGREGATE}

Liquid toxicants were impregnated into porous, expanded shale aggregate to establish a reservoir of these antifouling chemicals in the finished concrete. A list of the materials used in this work is presented in Table 1. The aggregate was first dried at $110^{\circ} \mathrm{C}$ to remove moisture. Two methods of incorporating liquid toxicant into the aggregate were evaluated. In the first, the aggregate was placed in a container, covered with creosote, and allowed to stand for 48 hours. The creosote was poured off, and the treated aggregate was allowed to drain, and then was spread on newspapers overnight to remove excess creosote from the surface. With this method, an uptake of creosote equal to $16.0 \%$ of the weight of the aggregate was realized. As a second method, vacuum impregnation of the aggregate was evaluated. In this procedure, the dried aggregate was placed in a vacuum chamber from which the air was removed. Creosote was admitted until the aggregate was covered, whereupon air was admitted to return the pressure in the chamber to atmospheric, forcing the creosote into the pores of the aggregate. After a 1-to-2-hour soaking time the creosote was removed, and the aggregate dried in the same manner as before. The vacuum impregnation method yielded a creosote uptake of $36.8 \%$ of the weight of the aggregate and was used in all subsequent work. Toxicants used to treat aggregate by the vacuum impregnation method were TBTO and a 60:40 mixture of TBTO and creosote by weight (Table 1). The average uptake of TBTO by the aggregate was $40 \%$, while the average uptake of the TBTO/creosote mixture was $38 \%$.

Before incorporation into concrete, the surface of the treated aggregate was rinsed to ensure a good bond between it and the cement paste. The several methods of rinsing that were evaluated included steam, hot water, cold water, trisodium phosphate solution, mineral spirits, and acetone/water solution. Based on the compressive strength of concrete made from aggregates rinsed by these methods, the acetone/water (90:10 by volume) was selected as the method to be used for all treated aggregate employed in this investigation. In this procedure, $3 \mathrm{~kg}$ of aggregate were shaken for $1 / 2$ to 1 minute with $1 \mathrm{~kg}$ of solvent. The solvent was immediately decanted from the aggregate, which was again spread on newspaper or burlap to complete solvent evaporation. The finished aggregate was either used immediately, or stored in sealed containers for future use. 


\section{B. PREPARATION OF - CONCRETE SPECIMENS}

The amount of the constituents of the concrete is given in their order of addition:

$40.3 \mathrm{lb}$ expanded shale aggregate (weight before impregnation)

$62.2 \mathrm{lb}$ sand

$\sim 21 \mathrm{lb}$ water

47.0 lb Portland cement, Type II

The wet concrete was mixed 3 minutes in a $1-3 / 4-\mathrm{ft}^{3}$ capacity pan-type mixer. The slump was then measured, ${ }^{7}$ and adjustments were made, if necessary, by adding more water. The finished wet concrete was then poured into 3 -inch-diameter by 6-inch-long molds to half fill them. The molds were placed on a vibrating table for several minutes, and then filled to the top. After vibration for several more minutes, the tops of the molds were finished with a trowel. The specimens were then placed in a $1.00 \%$ relative humidity (fog) room overnight. The next morning, the molds were removed, and the specimens returned to the fog room to cure for 28 days. The above concrete mix design was not changed when various amounts of dry toxicants were added. In one case; pea gravel was substituted for expanded shale aggregate to compare compressive strengths. This was done in such a way that the same volume of pea gravel was used as was occupied by 40.3 pounds of expanded shale aggregate; thus, 79.5 pounds of pea gravel were used in this mix.

The work reported here was begun in 1977 when antifouling concrete containing aggregate impregnated with TBTO/creosote ( $60: 40$ by weight) was prepared. 8,9 A set of control specimens was prepared using the same concrete mix design, but with untreated aggregate. The first set (Set 1) of specimens is designated as U1, U2, C1, and C2 in Table 2. Twelve replicates of each member of this set were placed in the channel to the harbor at Port Hueneme for 173 days. At periodic intervals during the exposure, ratings were made of the types and approximate numbers of the types of fouling that became attached to the specimens. When the specimens were removed from the ocean they were weighed, dried, and scraped free of the accumulated biofouling. At this time, it was decided that the more objective gravimetric ratings gave a better indication of the antifouling performance than the more subjective ratings done periodically during the exposure. Subsequently, all exposed specimens were weighed.

The remaining sets ( 2 through 5 in Table 2) were exposed at both Port Hueneme and from docks at the University of Miami in Biscayne Bay, Florida. Set 2 was comprised of four types of concrete (UT, PG, TB, \& KR) and was used to evaluate the effect of employing TBTO solely as a toxicant, and duplicated the TBTO/ creosote mixture used in the first set. There were, in effect, two types of controls in this set, because one member of this set was prepared with pea gravel to compare its compressive strength with concrete made with treated and untreated expanded shale aggregate. Ten replicate specimens of each type of concrete were exposed at both sites. 
Cuprous oxide was employed in Set 3, which was comprised of four types of concrete (V1-V4), both by itself and in combination with TBTO. The cuprous oxide was added to the other constituents of the concrete mix, and not impregnated into the aggregate. As in Set 2, TBTO was used by itself, but in this set the concentration of TBTO was halved in all cases by substituting an equal amount of pea gravel for treated aggregate. It was felt that this would both reduce the cost and increase the compressive strength of the resulting concrete. Five replicates of Set 3 were deployed at both sites. Also, five replicates of each member of Set 3 were placed in the submarine harbor at Key West to determine the resistance of these concretes to attack by pholads. No weighings were done, but visual inspections were made.

The effect of the chloroorganic compound methoxychlor was investigated in Set 4 (V5-V7). It was incorporated into the concrete alone and in combination with triphenyltin hydroxide (TPTH) and cuprous oxide. One of the members of this set consists of an organotin-polysiloxane polymer coating brush-applied to otherwise untreated cylinders. Polymerization took place when the substance was exposed to atmospheric moisture. The coverage was determined to be $9.05 \mathrm{mg} / \mathrm{cm}^{2}$ by weighing. In Set 4, all of the added toxicants were dry powders and were incorporated as such into the concrete mix. Controls from a previous untreated set were deployed at both sites along with five replicates of each candidate antifouling concrete.

Set 5 (NF) was prepared by wrapping and bonding a proprietary TBTOimpregnated elastomer (No Foul*) to untreated cylinders. No controls were prepared in this. case. Five samples were placed at each of the exposure sites.

\section{OCEAN EXPOSURE OF SPECIMENS}

Candidate antifouling concrete specimens were prepared as 3 -inch-diameter by 6-inch-long cylinders so that compressive strengths could be determined according to ASTM standards. ${ }^{10}$ To prepare the cylinders for exposure in the ocean, two small rectangular connector rings were threaded onto each of two nylon cable ties. One cable tie was tightly fastened about the circumference at each end of a cylinder with the connector rings on each tie located 180 degrees apart and in line with one another at opposite ends of the cylinder. Finally, an identifying number was melted into each nylon cable tie with a soldering pencil. Cylinders prepared for exposure by this method were attached to one another by placing still other nylon straps through the connector rings of adjacent specimens loosely enough that they hung at a distance from each other, forming what could be described as rungs of a ladder (Figure 1). Such groups of cylinders, each suspended horizontally, were hung from docks so that the topmost cylinder was beneath water during an extreme low tide. Typically, four cylinders were deployed in each group. At Port Hueneme, their position relative to one another in the group was changed periodically when they were weighed to confound the effect of the depth variable. Also, the place from which each group was suspended from the dock was periodically changed to prevent the entrance of effects of other variables into the results (sunlight, current, sedimentation, adjacent samples, etc).

*Trademark, B. F. Goodrich Co., Akron, OH. 
Port Hueneme was chosen as an exposure site because of its proximity to the Civil Engineering Laboratory. Specimens were exposed in the channel to this deep-water port where there is a good daily exchange of water from the ocean due to semi-diurnal tides which range from 4 to 9 feet. The temperature extreme of the surface water ranges from 9 to $22^{\circ} \mathrm{C} .{ }^{11}$

Key Biscayne, FL was chosen as a second exposure site because of climate and the availability of qualified personnel at the University of Miami to monitor the antifouling properties of the specimens. At Key Biscayne, the specimens were exposed in shallower water than at Port. Hueneme, but they were placed in a location where a 5-knot current flowed about them. It was felt that this relatively high flow rate would at least approach simulation of flow conditions one might encounter in the cold-water pipe of an OTEC platform. The tidal extremes at Key Biscayne are less than 2 feet, while the water temperature extremes in 1977 ranged from 15 to $32^{\circ} \mathrm{C}$. 12

\section{TEST FOR CORROSION OF REINFORCING RODS}

The effect on the corrosion of steel by toxicants employed in Sets 2 and 3 of candidate antifouling concrete (UT, PG, TB, KR, V1, V2, V3, and V4) was evaluated. One cylinder from each set was crushed, and the pieces were placed in a 5-liter plastic bucket which also contained one intact cylinder prepared with two $6 \mathrm{~d}$ nails in its interior. Ten weighed $6 \mathrm{~d}$ nails were added to each bucket, and seawater was allowed to trickle into the bucket so that it constantly overflowed. The seawater addition was from a sufficient height that splashing and consequent aeration of the contents of the bucket occurred. The nails were periodically removed, ultrasonically cleaned, rinsed with demineralized water, dried, and weighed to determine weight loss. When the experiment was terminated, the intact specimen was crushed, and the nails were examined for the presence of corrosion products. In a parallel experiment, cylinders prepared with $6 \mathrm{~d}$ nails both at the center and $1 \mathrm{~cm}$ from the wall were exposed to partial immersion for 446 days: Each of the above cylinders was placed vertically in a 2 -inch-deep pan through which seawater continually flowed. Inspections were periodically made to determine whether oxidation of the steel caused cracking or spalling of the concrete.

\section{E. BIOTOXICITY TESTS}

Two experiments were designed to determine the relative toxicity of certain toxicants employed as antifoulants. In the first, fertilized eggs of the red abalone, Haliotis rufescens, were used as test organisms. Toxicants tested included TBTO, TBTO/creosote, TBTO/Cu${ }_{2} \mathrm{O}$, and $\mathrm{Cu}_{2} \mathrm{O}$. Approximately 10,000 eggs were introduced into each of two 50-1iter plastic containers, one containing a control concrete specimen, and the second a specimen prepared using TBTO-impregnated aggregate. The next day the development of the eggs in both containers had terminated at the multicellular level. These concrete specimens, as well as others, were then placed in flowing seawater and allowed to leach for 102 days. The experiment was repeated using 17-liter containers with approximately 5,000 fertilized eggs in each. 
The second experiment was designed to measure the relative concentrations of various toxicants required to kill larvae of $\mathrm{H}$. rufescens.

These toxicants were TBTO, TBTO/creosote, and methoxychlo $\bar{r} / \mathrm{TPTH} / \mathrm{Cu}_{2} 0$. In this experiment, both treated and control concrete cylinders were. leached for 12 days, then placed in plastic pails containing. 4.3 liters of seawater that was filtered to 1 micron and sterilized with ultraviolet radiation. The cylinders were immersed for 2,20 , and 200 minutes in such a way that no part of the cylinder contacted the container. Larvae were then introduced, and the effect of the three toxicant concentrations resulting from the three immersion times was monitored by periodic microscopic observation of the larval development. 


\section{FINDINGS}

\section{A. ANTIFOULING PROPERTIES}

1. Set 1. After 173 days of exposure, the concrete prepared with the TBTO/creosote-impregnated aggregate accumulated $44 \%$ as much biofouling as the untreated control. Table 3 presents these data and summarizes the final subjective evaluations made after 163 days of exposure.

2. Set 2. In this set, TBTO alone did not perform as well as the TBTO/creosote mixture which was used in the same manner as in Set 1 (see Table 4). Cylinders prepared with TBTO alone accumulated $83 \%$ as much biofouling as the control after 596 days at Port Hueneme compared with $52 \%$ for the TBTO/creosote mixture (Figure 2). At Key Biscayne, biofouling was $96 \%$ of the control for TBTO alone, and $59 \%$ for TBTO/creosote after 524 days of exposure (Figure 3). (The specimens made using pea gravel for compressive strength tests were removed from the ocean after 401 days at Port Hueneme and after 241 days at Key Biscayne.)

3. Set 3. TBTO was employed at half the concentration used in Set 2 , both alone and combined with cuprous oxide. Cuprous oxide alone was also evaluated and found to have no effect at the concentration used. At Port Hueneme the weight increases after 153 days due to biofouling of members of this set compared to the control were: TBTO alone, $81 \%$; TBTO/Cu $\mathrm{O}, 69 \%$; and $\mathrm{Cu}_{2} \mathrm{O}$ only, 93\% (Figure 4). Data from Key Biscayne after 283 days showed the same trend: TBTO alone, $92 \%$; $\mathrm{TBTO} / \mathrm{Cu}_{2} 0,93 \%$; and $\mathrm{Cu}_{2} \mathrm{O}$ alone, $116 \%$ (Figure 5 ). The specimens in this set at Key West have not shown any signs of attack by pholads. They are suspended a few feet from a 67-year-old concrete pier that exhibits evidence of pholad activity.

4. Set 4. This set was prepared to investigate the antifouling properties of two basic toxicants: methoxychlor and a proprietary. organotin coating. Methoxychlor was employed alone and in combination with TPTH and $\mathrm{Cu}_{2} \mathrm{O}$. At Port Hueneme, the weight increase of this set versus an untreated control after 153 days was: methoxychlor alone, $124 \%$; methoxychlor/TPTH/ $\mathrm{Cu}_{2} \mathrm{O}, 65 \%$; and organotin coating, $42 \%$ (Figure 4 ). At Key Biscayne, the results for replicates of this set after 139 days were: methoxychlor, $99 \%$; methoxychlor $/ \mathrm{TPTH} / \mathrm{Cu}_{2} \mathrm{O}, 90 \%$; and organotin coating, $66 \%$ (Figure 6 ).

5. Set 5. The cylinders covered with the organotin-impregnated rubber accumulated an average of $15.8 \mathrm{gm}$ of biofouling after 60 days of exposure at Port Hueneme. No data are available at this time on the replicates exposed in Key Biscayne.

\section{B. COMPRESSIVE STRENGTH}

Various solvents for washing aggregate impregnated with TBTO/creosote $(60: 40)$ were tested. The prepared specimens had 7-day compressive strengths shown below when tested according to ASTM Method C-873-77T: ${ }^{10}$ 
Wash Solvent

None (unimpregnated control)

Acetone/water $(90: 10)$

None

Mineral spirits

Trisodium phosphate solution
Compressive Strength (psig)

3,920

3,660

3,190

2,960

2,720

The acetone/water solution was selected as the solvent, and the concrete cylinders of Set 1 and all subsequent sets employing treated aggregate were rinsed with this solution. After 6 months of exposure at Port Hueneme, the compressive strength of treated cylinders of Set 1 was 4,200 psi, while that of untreated controls was 5,140 psi.

The 28-day compressive strengths of cylinders from Set 2 were determined to be:

$\begin{array}{lll}\text { Control } & \text { (UT) } & 5,710 \mathrm{psig} \\ \text { Pea.gravel } & \text { (PG) } & 6,080 \mathrm{psig} \\ \text { TBTO } & \text { (TB) } & 4,840 \mathrm{psig} \\ \text { TBTo/creosote } & \text { (KR) } & 3,200 \mathrm{psig}\end{array}$

After 9 months of exposure in Key Biscayne, the compressive strength of 3 members of this set was again determined: UT, 6710 psig; TB, 6,090 psig; and $K R, 3,840$ psig.

Set 3 specimens had 28 -day compressive strengths as follows:

$\begin{array}{lll}\text { Control } & \text { (V4) } & 4,660 \text { psig } \\ \text { TBTO } & \text { (V1) } & 6,010 \text { psig } \\ \text { TBTO } / \mathrm{Cu}_{2}{ }^{\circ} & \text { (V2) } & 5,360 \text { psig } \\ \mathrm{Cu}_{2} \mathrm{O}^{\circ} & \text { (V3) } & 5,330 \mathrm{psig}\end{array}$

The compressive strength of the fourth set of cylinders was not determined.

C. EFFECT OF ADDITIVES ON CORROSION OF SIMULATED REINFORCING ROD

The loss in weight of nails used to simulate reinforcing rod versus time is presented in Figure 7 . All of the candidate antifouling chemicals evaluated in this test inhibited rather than accelerated the corrosion of the steel except cuprous oxide, and that only when used alone. The presence of TBTO, creosote, or a mixture of these compounds caused a significant reduction in the rate at which the steel corroded.

After 446 days of exposure, the percent weight loss of the ten replicate nails exposed to the various concretes was: 
Treatment

Control

$\mathrm{Cu}_{2} \mathrm{O}$

$\mathrm{TBTO} / \mathrm{Cu}_{2} \mathrm{O}$

TBTO

TBTO/creosote
Percent Weight Loss*

$29.7,29.6,28.9$

28.3

23.0

$22.2,20.2$

17.9

In Figure 7, the results from those treatments which were duplicated are averaged.

In another experiment, none of the cylinders prepared with nails placed at the center and $1 \mathrm{~cm}$ from the surface showed signs of cracking or spalling after 445 days. These cylinders were exposed so that the bottom one-third was immersed in continually flowing seawater, while the top two-thirds of the cylinder was in air to simulate the hull of a concrete vessel.

\section{BIOTOXICITY}

Two experiments were performed to evaluate biotoxicity; the first using fertilized eggs of the red abalone Haliotis rufescens, and the second using larvae of the same organism.

In the initial part of the first experiment, it was found that an untreated control specimen caused cessation of development and death of fertilized eggs, so specimens were leached in flowing seawater for 102 days and the test repeated. Concrete cylinders prepared using TBTO, TBTO/creosote, TBTO/ $\mathrm{Cu}_{2} \mathrm{O}, \mathrm{Cu}_{2} \mathrm{O}$, and an untreated control were evaluated. Approximately 5,000 fertilized eggs were placed in 17 liters of seawater in a polyethylene bucket, into which a test cylinder was then placed. After 18 hours, the development of the eggs was observed microscopically. All eggs in seawater buckets which contained a treated specimen had ceased development, while eggs in seawater. with a control specimen were developing normally. Some differences were observed in the stages to which development had progressed before death and in the morphology of the organism, depending on the toxicant present. ${ }^{13}$ This is of academic interest, perhaps, but all the toxicants did cause cessation of development at some stage.

The second experiment used the larvae of $\mathrm{H}$. rufescens as the test organism. In this test three toxicant systems were evaluated at three different concentrations. Cylinders prepared using TBTO, TBTO/creosote, and methoxychlor/TPTH/ $\mathrm{Cu}_{2} \mathrm{O}$ were exposed to seawater in polyethylene pails containing 4.3 liters of seawater for $2 ; 20$, and 200 minutes to obtain increasing concentrations of toxicant. They were previously leached for 12 days in flowing seawater to establish a steady-state diffusion rate. An untreated control was similarly employed. Approximately 1,000 larvae were added to each pail, and the progress of development was observed

*Each entry is data averaged from ten replicates. 
perriodically through a microscope. Table 5 shows the effect of the various toxicant's at each concentration as a function of time. Differences in the morphology of the larvae exposed to the different toxicants were again observed. It is interesting to notè that methoxychlor, a DDT analog, produced effects on the larvae more slowly than did other toxicants. Generally, the TBTO and TBTO/creosote caused necrosis, followed eventually by cellular disassociation. This effect is similar morphologically to that of elevated temperature. ${ }^{14}$ Methoxychlor caused abnormalities in the development of body parts. After 32 hours, death occurred in all cases where a toxicant was present. The development of larvae in pails which contained the duplicate set of controls continued normally for 7 days, after which the experiment was terminated. 
IV. DISCUSSION

\section{A.. $\quad \operatorname{COST}$ OF MATERIALS}

Toxicant cost varies greatly from one system to another. Because an OTEC plant may use a large amount of concrete, the cost of the material used as an antifoulant would be a significant consideration. A comparison of the raw material cost of the various toxicants employed in this investigation is given below in 1979 dollars:

\section{Treatment}

TBTO $(\$ / 1 b)$

Creosote $(\$ / 1 b)$

$\mathrm{Cu}_{2} \mathrm{O}(\$ / 1 \mathrm{~b})$

Methoxychlor ( $\$ / 1 b)$

TPTH ( $\$ / 1 b)$

Nofoul rubber, 0.08-in.-thick $\left(\$ / \mathrm{ft}^{2}\right)$

Organotin polymer ( $\$ / g a l)$
Cost

6.55

0.10

1.30

1.40

8.16

4.85

50.00

One of the better toxicant systems employs $60 \%$ TBTO and $40 \%$ creosote impregnated into aggregate. Because of the high cost of TBTO relative to creosote, concrete containing a higher ratio of creosote to TBTO should be considered. It is worth noting that $100 \%$ TBTO is less effective an antifoulant than the TBTO/creosote mixture employed. The immediate conclusion is that the creosote provides antifouling properties not present in TBTO alone. It has been observed, however, that concrete specimens prepared with TBTO/creosote and left in a fog room for a few months became covered with a layer of toxicant that had oozed from the concrete. This phenomenon is not observed in specimens prepared using TBTO alone. Possibly the creosote acts as a vehicle for the TBTO, allowing it to move more readily through the concrete to the surface where it is effective as an antifoulant. This phenomenon has been demonstrated to be of considerable importance. ${ }^{15}$ If this is the case, other solvents may be even more effective.

The cost of toxicant in concrete prepared using only TBTO at $8 \%$ based on the weight of the other constituents is $\$ 65 / \mathrm{ft}^{3}$. When TBTO/creosote is used at $60 / 40$ the cost is $\$ 40 / \mathrm{ft}^{3}$. This is significant both from the standpoint of reducing cost and of preparing concrete with better antifouling properties. Further dilution of TBTO by creosote would reduce the cost still more and could yield a better product. If a 0.5 -inchthick layer of the treated concrete is spread over standard concrete (as it might be in an OTEC application), the toxicant cost is $\$ 1.64 / \mathrm{ft}^{2}$ if $8 \%$ of the concrete weight is TBTO/creosote.

The specimens prepared using methoxychlor/TPTH/Cu $\mathrm{O}$ appear to possess good antifouling properties. At the concentrations used, however, the cost of toxicants in this set is $\$ 63.40 / \mathrm{ft}^{3}$. This amounts to $\$ 2.64 / \mathrm{ft}^{2}$ when applied at a thickness of $0.5 \mathrm{inch}$. 
Two sets of cylinders were evaluated where a coating was placed on otherwise untreated, concrete. Both seem effective as antifoulants. The first of these is a brush-applied organotin polymer which would, at the level employed in this experiment, cost $\$ 0.10 / \mathrm{ft}^{2}$. It should be able to be applied in a coating thicker than the $9 \mathrm{mg} / \mathrm{cm}^{2}$ used, perhaps by repetitive applications. The second is a proprietary organotinimpregnated elastomer (NoFoul ${ }^{\circledR}$ rubber). The cost of the materials and adhesives in this system is $\$ 4.85 / \mathrm{ft}^{2}$. . A thickness of 0.08 inch is assumed. The manufacturer produces sheets having greater thicknesses at higher costs :

\section{B. EXPOSURE SITES AND METHODS}

Differences in the rate of attachment and growth of fouling organisms at the two sites were expected. Figures 2-6 show these differences. As a. general rule, the first members of the fouling community observed on specimens at Key Biscayne were algae. Barnacles soon followed, eventually covering the specimen completely. At Port Hueneme, where the water temperature is lower, the sequence of attachment of fouling organisms was slower so that many different organisms would be found at one time on specimens where there was attachment. Each time a set of treated specimens was exposed, a set of controls was also exposed. The importance of this cannot be overstated. The number of larvae of barnacles, for example, in seawater varies tremendously at different times throughout the year and reaches maxima at different times in different years. ${ }^{16}$ Similarly, one is cautioned not to compare weight increases of specimens exposed at one site versus those exposed at another. The only way an evaluation of the effectiveness of a given toxicant can be made is by comparing the weight increase of specimens prepared with it versus those of control specimens exposed at the same time in the same place.

\section{OBJECTIVE RATINGS}

Table 3 shows one subjective rating made on the first batch of specimens and the final objective rating made on the same specimens. The objective gravimetric method yields a more easily handled numerical rating that can be readily plotted (Figures 2-6). Furthermore, different individuals using this method will arrive at the same figure. A subjective rating is highly dependent upon the judgment of the rater, which varies from person to person and from day to day. For these reasons, the objective weighing method of evaluation was employed in this experiment. No major differences in types of fouling have been noted between treated specimens and untreated controls; only amounts.

\section{PERSISTENCE OF ORGANOTINS}

Prior to this study, a test to determine the life of an organotin in a seawater environment was initiated. A concrete panel made with TBTOimpregnated aggregate, cement, and water was prepared by Muraoka in May 1970, and placed in the harbor at Port Hueneme. ${ }^{4}$ In November 1977, it was removed from the harbor and cut with a concrete saw so that a representative sample of both the interior and the outermost $3 \mathrm{~mm}$ were obtained. 
A portion of the sample from the interior was extracted three times with acetone and four times with benzene. Duplicates of these samples and a control which contained a known amount of TBTO were analyzed for tin by $x$-ray fluorescence spectroscopy. The percent tin in each was:

$\underline{\text { Item }}$

Exposed sample
Location.

exterior

interior

interior (extracted) $\underline{\text { Tin }(\%)}$

$1.47,1.35$

$1.52,1.52$

$0.24,0.22$

$4.75,4.85$

Control. standard

The standard was known to contain $14.8 \%$ tin, so the results should be raised about three-fold. It will be seen, however, that the amount of tin in the sample removed from the exterior of the specimen is nearly the same as that removed from its interior. Furthermore, most of the tin present in the specimen was extractable in organic solvents; thus, it had not degraded to inorganic tin compounds during the 6-1/2 years it. was in the ocean. Thus, it can be concluded that TBTO remains bound in an organic molecule for long periods of time in antifouling concrete exposed in seawater. 


\section{SUMMARY AND CONCLUSIONS}

Various candidate antifouling concretes were prepared and exposed in the ocean at two sites. The effects of the chemicals used as antifoulants were investigated. Toxicity tests of the antifoulants on specific organisms were performed, and the effect of the antifoulants on reinforcing rods was investigated. Results of these investigations are summarized as follows:

1. Concrete into which toxicants were incorporated accumulated, at best, about half as much fouling as untreated controls. This ability to resist fouling is insufficient for practical use in the present form. Two systems in which toxicant-bearing coatings were applied to concrete show promise, but they have been under investigation for only a short time.

2. A mixture of TBTO and creosote (60:40 by weight) impregnated into aggregate from which concrete is made yields a product with better antifouling properties than concrete prepared from aggregate impregnated with TBTO only. This is highly significant from an economic standpoint.

3. Concrete prepared with TBTO-impregnated aggregate and cuprous oxide possesses some antifouling properties. Cuprous oxide, when employed as the sole antifoulant (at $2 \%$ by weight of the total), did not provide antifouling properties.

4. Concrete containing methoxychlor/TPTH/cuprous oxide has demonstrated antifouling properties, while concrete prepared using methoxychlor alone exhibited none. These specimens have been exposed for only five months.

5. A proprietary organotin-polysiloxane polymer coating has been under evaluation for 5 months. Preliminary data indicate that this coating prevents fouling and is low in cost.

6. A proprietary organotin-impregnated rubber sheeting has demonstrated excellent antifouling properties for 2 months at Port Hueneme. Its cost is. greater than that of the organotin-polysiloxane coating, both for materials and application.

7. The cost of the various antifouling concretes varies considerably and would be an important consideration in the selection of one system versus another.

8. Structurally sound concrete can'be prepared using aggregate impregnated. with the antifoulants employed in this investigation.

9. All of the candidate antifoulants considered for possible use caused a reduction in the corrosion rate of simulated steel reinforcing rods.

10. Some of the candidate antifouling concretes were exposed in an area of the ocean where rock-boring clams (pholads) are known to exist. In the $1-1 / 2$ years of this test, none of these concretes (including the untreated controls) showed evidence of attack by the pholads. 
11. Biotoxicity tests were performed with certain of the toxicants on the eggs and larvae of the red abalone Haliotis rufescens. All of the toxicants proved to be fatal to this organism at all concentrations tested.

12. A TBTO-containing antifouling concrete panel prepared in an earlier investigation and exposed in the ocean $6-1 / 2$ years had a tin concentration essentially the same at both the surface and the interior. The tin at the interior was shown to still exist in an organic molecule. 
VI. RECOMMENDATIONS

Concrete made with aggregate impregnated with a TBTO/creosote has continued to exhibit antifouling properties after $1-1 / 2$ years of exposure. The ratio of TBTO to creosote might well be lowered to reduce the cost of the impregnant. Because it is known that this mixture of impregnants displays a latent period before forming a really good protective layer; the effect of time and temperature should be investigated. If it is determined that creosote should not be used in concrete for an OTEC structure, other hydrocarbon vehicles for TBTO should be considered.

After 5 months of exposure, concrete containing methoxychlor/TPTH/ $\mathrm{Cu}_{2} \mathrm{O}$ exhibits some antifouling properties. The exposure of these specimens will continue, and the efficacy of this concrete should be determined after a longer exposure. The organotin polysiloxane and NoFoul ${ }^{\circledR}$ coatings exhibit excellent antifouling properties, but these also have been under test for only 5 months. The organotin polysiloxane coating is the least expensive of any of the antifouling systems investigated. 
Dr. Shirley Pomponi-Taylor, now of the University of Maryland, exposed test specimens and accumulated weight data: at the Key Biscayne exposure site. Mr. John Keeton and Mr. John Crahan of CEL were responsible for the mix design and preparation of the concrete test specimens.. 


\section{REFERENCES}

1. Lunn, Iver. Antifouling. London, BCA Publications, 1974.

2. Woods Hole Oceanographic Institution. Marine Fouling and.Its Prevention. Menasha, WI, Geo. Banta Co., 1952, p 17.

3. Ibid. pp 11-14.

4. Civil Engineering Laboratory. Technical Note N-1211, Antifouling Concrete--Preliminary Report, by J. S. Muraoka, Port Hueneme, CA, Jan . 1972 .

5. Civil Engineering Laboratory. Technical Note N-1392, Antifouling Marine Concrete, by. J. S. Muraoka and H. P. Vind, Port Hueneme, CA, May 1975 .

6. U. S. Patent $3,784,357$ "Protective Surfaces or Liners for Sub-Aqueous Structures" 8 Jan 74 .

7. ASTM C143-78, Standard Test Method for Slump of Portland Cement Concrete. 1979 Annual Book of ASTM Standards, Part 14, American Society for Testing and Materials, Philadelphia, PA, 1979, pp 97-8.

8. Civil Engineering Laboratory. Technical Memorandum M-52-77-8, Preliminary Investigation of Methods to Increase the Strength of Antifouling Marine Concrete, by H. P. Vind and J. R. Keeton, Port Hueneme, CA, May 1977.

9. Civil Engineering Laboratory. Technical Memorandum M-52-78-03, Antifouling Marine Concrete, First Quarterly Progress Report, by H. P. Vind, J. R. Keeton, and C. W. Mathews, Port Hueneme, CA, Feb 1978.

10. ASTM C873-77T, Tentative Test Method for Compressive Strengths of Concrete Cylinders Cast in Place in Cylindrical Molds. 1979 Annual Book of ASTM Standards, Part 14, American Society for Testing and Materials, Philadelphia, PA, pp 535-537.

11. Coast and Geodetic Survey. Publication no. 31-3, 2nd edition: Surface Water Temperature and Density for the Pacific Coast of North \& South America and Pacific Ocean Islands. Rockville, MD, 1967.

12. Dr. Hillary Moore. University of Miami, Rosenstiel School of Marine and Atmospheric Science, unpublished report.

13. Ab-Lab. Effective Concentration of Antifouling Agents, by John D. McMullen. Port Hueneme, CA, Nov. 1978.

14. Ab-Lab. Effect of Known Toxicants on Development/Mortality of Abalone Trochophore Larvae, by John D. McMullen. Port Hueneme, CA, July 1979. 
15. Paul, D. R., and Harris: Controlled Release of Polymeric Formulations, Washington, DC. American Chemical Society Symposium. Series 33, 1976, pp 239-247.

16. Woods Hole Oceanographic Institution. Marine Fouling and Its

Prevention. Menasha, WI, Geo. Banta Co., 1952, Chapter 5. 
TABLE 1. MATERIALS USED AND MANUFACTURERS

\begin{tabular}{|c|c|c|}
\hline Item & Description or Designation & Source \\
\hline Adhesive & Super Weatherstrip Adhesive, Part No. 8003 & $\begin{array}{l}\text { 3M Co: } \\
\text { Adhesives, Coatings \& Sealers Div. } \\
\text { St. Paul, } 55101\end{array}$ \\
\hline Aggregate & Ridgelite-Rocklite, $3 / 8^{\prime \prime}$ & $\begin{array}{l}\text { Ceramic Lightweight Aggregate } \\
650 \text { S. Grand Ave. } \\
\text { Los Angeles, CA } 90017\end{array}$ \\
\hline Cable Ties & Pan-ty 非PT $3 H-D$ & $\begin{array}{l}\text { Pandruit Corp. } \\
\text { Tinley Park, IL } 60477\end{array}$ \\
\hline Cement & ASTM Type II & . \\
\hline Creosote & $\begin{array}{l}\text { Federal Specification TT-C-645b, Class III, } \\
\text { Creosote 0il }\end{array}$ & $\begin{array}{l}\text { Koppers Co. } \\
\text { Tar Products Div. } \\
\text { Fontana, CA }\end{array}$ \\
\hline $\mathrm{Cu}_{2} \mathrm{O}$ & Cuprous oxide, powder, $98.6 \%$ & . \\
\hline Methoxychlor & 2,2-bis (p-methoxyphenyl)-1,1,1-trichloroethane & $\begin{array}{l}\text { E. I: DuPont, de Nemours \& Co. } \\
\text { Wilmington, DE }\end{array}$ \\
\hline Nails & $6-d$ FSN 5315-00-889-2744 & - \\
\hline Nofoul ${ }^{B}$ & TBTO-impregnated rubber sheeting & $\begin{array}{l}\text { B. F: Goodrich \& Co. } \\
\text { Akron, OH }\end{array}$ \\
\hline Organotin Polymer & Siloxane-tin polymeric coating & $\begin{array}{l}\text { Ameron Corp. } \\
\text { Monterey Park, CA }\end{array}$ \\
\hline Sand & Concrete sand (river) & \\
\hline TBTO & bis (tri-n-butyltin) oxide & $\begin{array}{l}\text { M \& T Chemicals, Inc. } \\
\text { Rahway, NJ } 07065\end{array}$ \\
\hline TPTH & triphenyltin hydroxide & $\begin{array}{l}\text { M \& T Chemicals Inc. } \\
\text { Rahway, NJ } 07065\end{array}$ \\
\hline
\end{tabular}


TABLE 2. TOXICANTS EMPLOYED IN ANTIFOULING CONCRETES

\begin{tabular}{|c|c|c|}
\hline $\begin{array}{l}\text { Set } \\
\text { No. }\end{array}$ & Symbol & Toxicant (Concentration) ${ }^{a}$ \\
\hline 1 & $\begin{array}{ll}\mathrm{U} 1, & \mathrm{II} 2 \\
\mathrm{C} 1, & \mathrm{C} 2\end{array}$ & $\begin{array}{l}\text { control } \\
\text { TBTO/creosote, } 60: 40(9.0)\end{array}$ \\
\hline 2 & $\begin{array}{l}\text { UT } \\
\text { PG } \\
\text { TB } \\
\text { KR }\end{array}$ & $\begin{array}{l}\text { control } \\
\text { control } \\
\text { TBTO }(9.7) \\
\text { TBTO/creosote, } 60: 40(8.8)\end{array}$ \\
\hline 3 & $\begin{array}{l}\text { V1 } \\
\text { V2 } \\
\text { V3 } \\
\text { V4 }\end{array}$ & $\begin{array}{l}\text { TBTO }(4.3) \\
\text { TBTO }(4.3) / \mathrm{Cu}_{2} \mathrm{O}(2.0) \\
\mathrm{Cu}_{2} \mathrm{O}(2.0) \\
\text { control }\end{array}$ \\
\hline 4 & $\begin{array}{l}\text { V5 } \\
\text { V6 } \\
\text { V7 }\end{array}$ & $\begin{array}{l}\text { Methoxychlor }(4.3) \\
\text { Methoxychlor }(4.3) \text {, TPTH }(4.8), \mathrm{Cu}_{2} \mathrm{O} \text { (4.7) } \\
\text { organotin polymer (unknown) }\end{array}$ \\
\hline 5 & NF & NoFoul rubber (unknown) \\
\hline
\end{tabular}

${ }^{a}$ Percent by weight of all other constituents. 
TABLE 3. SUMMARY RATINGS OF FOULING OF FIRST

SET OF SPECIMENS AT PORT HUENEME

a: Subjective Rating

\begin{tabular}{|c|c|c|}
\hline Fouling Organism & $\begin{array}{l}\text { Treated Specimens } \\
\quad(163 \text { days })\end{array}$ & $\begin{array}{l}\text { Untreated Specimens } \\
\text { (163 days) }\end{array}$ \\
\hline $\begin{array}{c}\text { Barnacles } \\
\text { Bryozoa } \\
\text { Tunicates } \\
\text { Mussels }\end{array}$ & $\begin{array}{l}3,7,0, \mathrm{~F}^{*}, 5,2 \\
5,7,0,9,2,2 \\
\mathrm{~F}, \mathrm{~F}, \mathrm{~F}, \mathrm{H}^{*}, \mathrm{~F}, \mathrm{M}^{*} \\
\mathrm{~F}, \mathrm{~F}, \mathrm{~F}, \mathrm{~F}, \mathrm{~F}, \mathrm{H} \\
\quad \mathrm{F}, \mathrm{F}, \mathrm{F}, \mathrm{O}, \mathrm{F}, \mathrm{F} \\
\mathrm{F}, \mathrm{F}, \mathrm{F}, \mathrm{F}, \mathrm{F}, \mathrm{F} \\
\\
0,0,0,0,0,1 \\
0,0,0,0,0,0\end{array}$ & 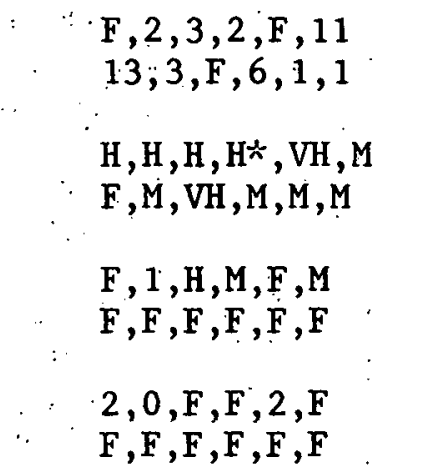 \\
\hline
\end{tabular}

$* 0=$ none

$F=$ few,$M=$ medium,$H=$ heavy,$V H=$ very heavy

b: Objective Rating

\begin{tabular}{|c|c|c|}
\hline \multirow{2}{*}{ Cylinders } & \multicolumn{2}{|c|}{ Mean Weight Increase (gm) After 173 Days-- } \\
\cline { 2 - 3 } & Treated Specimens & Untreated Specimens \\
\hline Wet & 87.0 & 197.2 \\
Dry & 10.12 & 38.54 \\
\hline
\end{tabular}


TABLE 4. WEIGHT OF ACCUMULATED BIOFOULING

\begin{tabular}{|c|c|c|c|c|c|}
\hline \multirow[b]{2}{*}{ Set No. } & \multirow[b]{2}{*}{ Toxiçant } & \multicolumn{2}{|c|}{ Port Hueneme } & \multicolumn{2}{|c|}{ Key Biscayne } \\
\hline & & $\begin{array}{c}\text { Weight } \\
\text { (gm) }\end{array}$ & Days & $\begin{array}{c}\text { Weight } \\
(\mathrm{gm})\end{array}$ & Days \\
\hline 1 & $\begin{array}{l}\text { Controi } \\
\text { TBTO/creosote }\end{array}$ & $\begin{array}{r}197.2 \\
87.0\end{array}$ & $\begin{array}{l}173 \\
173\end{array}$ & --- & \\
\hline 2 & $\begin{array}{l}\text { Control } \\
\text { Control } \\
\text { TBTO } \\
\text { TBTO/creosote }\end{array}$ & $\begin{array}{l}447.4 \\
234.6 \\
372.8 \\
234.0\end{array}$ & $\begin{array}{l}596 \\
401 \\
596 \\
596\end{array}$ & $\begin{array}{l}734.6 \\
623.3 \\
705.8 \\
433.6\end{array}$ & $\begin{array}{l}524 \\
241 \\
524 \\
524\end{array}$ \\
\hline 3 & $\begin{array}{l}\text { TBTO } \\
\text { TBTO } / \mathrm{Cu}_{2} \mathrm{O} \\
\mathrm{CU}_{2} \mathrm{O} \\
\text { Control }\end{array}$ & $\begin{array}{l}71.8 \\
61.4 \\
82.5 \\
89.1\end{array}$ & $\begin{array}{l}153 \\
153 \\
153 \\
153\end{array}$ & $\begin{array}{l}1,320 \\
1,331 \\
1,661 \\
1,432\end{array}$ & $\begin{array}{l}283 \\
283 \\
283 \\
283\end{array}$ \\
\hline 4 & $\begin{array}{l}\text { Methoxychlor } \\
\text { Methoxychlor/TPTH } / \mathrm{Cu}_{2}{ }^{0} \\
\text { Polymeric tin } \\
\text { Control }\end{array}$ & $\begin{array}{r}110.2 \\
57.6 \\
37.1 \\
89.1\end{array}$ & $\begin{array}{l}153 \\
153 \\
153 \\
153\end{array}$ & $\begin{array}{r}154.4 \\
139.7 \\
103.2 \\
155.3\end{array}$ & $\begin{array}{l}139 \\
139 \\
139 \\
139\end{array}$ \\
\hline 5 & NoFoul rubber & 15.8 & 60 & --- & \\
\hline
\end{tabular}


TABLE 5. EFFECT OF TOXICANT AND TOXICANT CONCENTRATION ON LARVAE OF HALISTIS RUFESCENS

\begin{tabular}{|c|c|c|c|c|c|c|c|c|c|c|}
\hline \multirow[b]{2}{*}{ Toxicant } & \multirow{2}{*}{$\begin{array}{c}\text { Immersion } \\
\text { Time of } \\
\text { Specimen } \\
\text { (min) }\end{array}$} & \multicolumn{9}{|c|}{ Larvae Condition After -- } \\
\hline & & $\begin{array}{l}10 \\
\text { Min }\end{array}$ & $\begin{array}{l}1 \\
\mathrm{Hr}\end{array}$ & $\begin{array}{l}\sim 2 \\
\mathrm{Hr}\end{array}$ & $\begin{array}{c}2-1 / 2 \\
\mathrm{Hr}\end{array}$ & $\begin{array}{c}3-1 / 2 \\
\mathrm{Hr}\end{array}$ & $\begin{array}{l}5 \\
\mathrm{Hr}\end{array}$ & $\begin{array}{c}6-3 / 4 \\
\mathrm{Hr}\end{array}$ & $\begin{array}{l}24 \\
\mathrm{Hr}\end{array}$ & $\begin{array}{l}32 \\
\mathrm{Hr}\end{array}$ \\
\hline \multirow[t]{3}{*}{ TBTO } & 2 & $\mathrm{~N}$ & L & C & C & D & & & & \\
\hline & 20 & $\mathrm{~N}$ & L & C & C & D & & & & \\
\hline & 200 & L & L & D & & & & & & \\
\hline \multirow[t]{3}{*}{ TBTO/Creosote } & 2 & $\mathrm{~N}$ & $\mathrm{~N}$ & L & L & L & $\mathrm{L}$ & C & $\mathrm{D}$ & \\
\hline & 20 & N & $\mathrm{L}$ & $\mathrm{L}$ & L & C & $\mathrm{C}$ & C & $\mathrm{D}$ & \\
\hline & 200 & L & L & L & C & C & $\mathrm{D}$ & & & \\
\hline \multirow[t]{3}{*}{ Methoxychlor/TPTH/ $\mathrm{Cu}_{2} \mathrm{O}$} & 2 & N & $\mathrm{N}$ & $\mathrm{N}$ & N & $\mathrm{N}$ & N & $\mathrm{N}$ & $\mathrm{L}$ & $\mathrm{D}$ \\
\hline & 20 & N & $\mathrm{N}$ & $\mathrm{N}$ & $\mathrm{N}$ & N & $\mathrm{N}$ & $\mathrm{N}$ & L & D \\
\hline & 200 & N & $\mathrm{N}$ & $\mathrm{L}$ & L & L & C & D & & \\
\hline
\end{tabular}

$\mathrm{N}=$ No visible effect

$\mathrm{L}=$ Live, most immobile

C = Cellular disassociation or abnormal development

$\mathrm{D}=$ Dead 


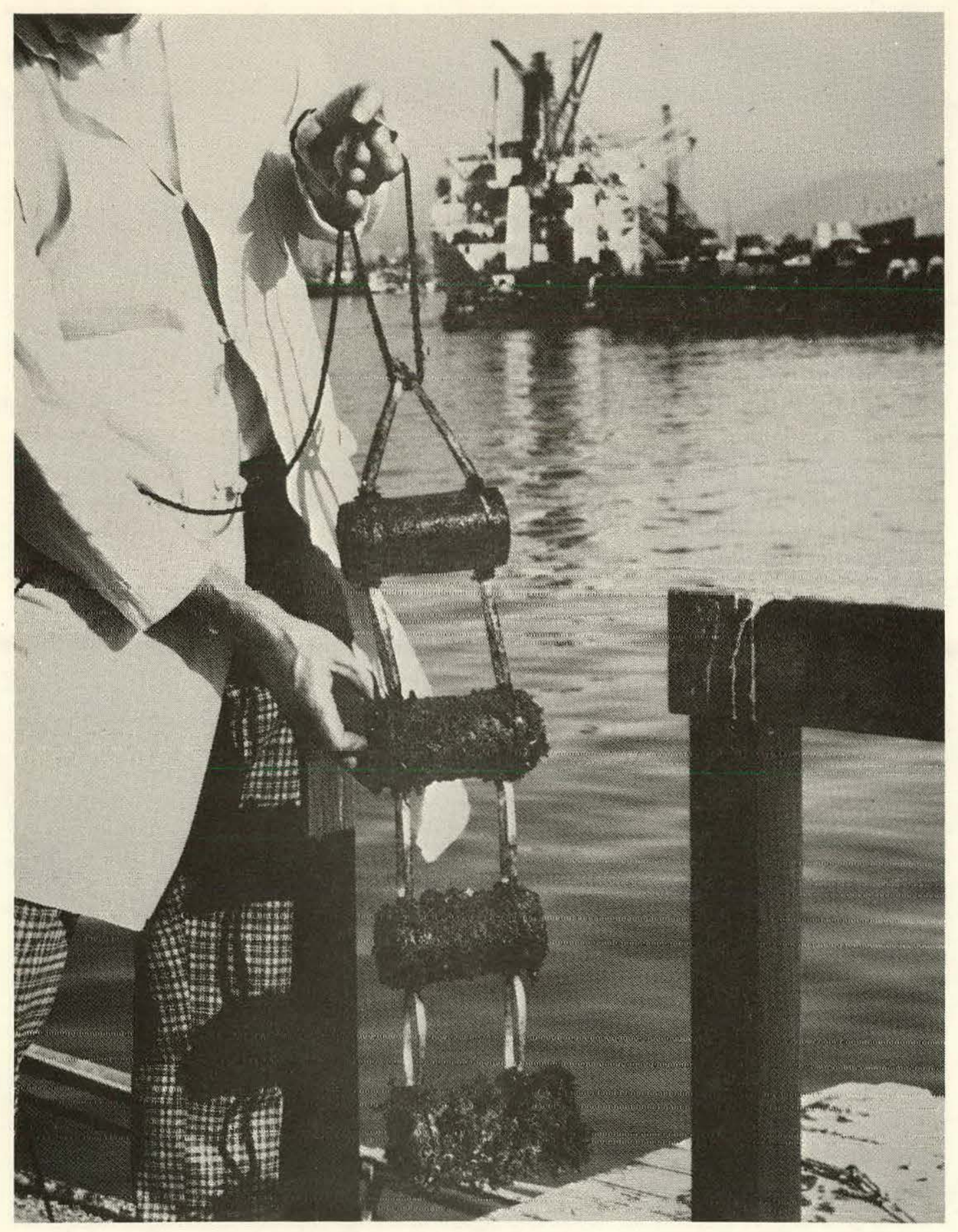

Figure 1. Typical arrangement for deploying specimens. 


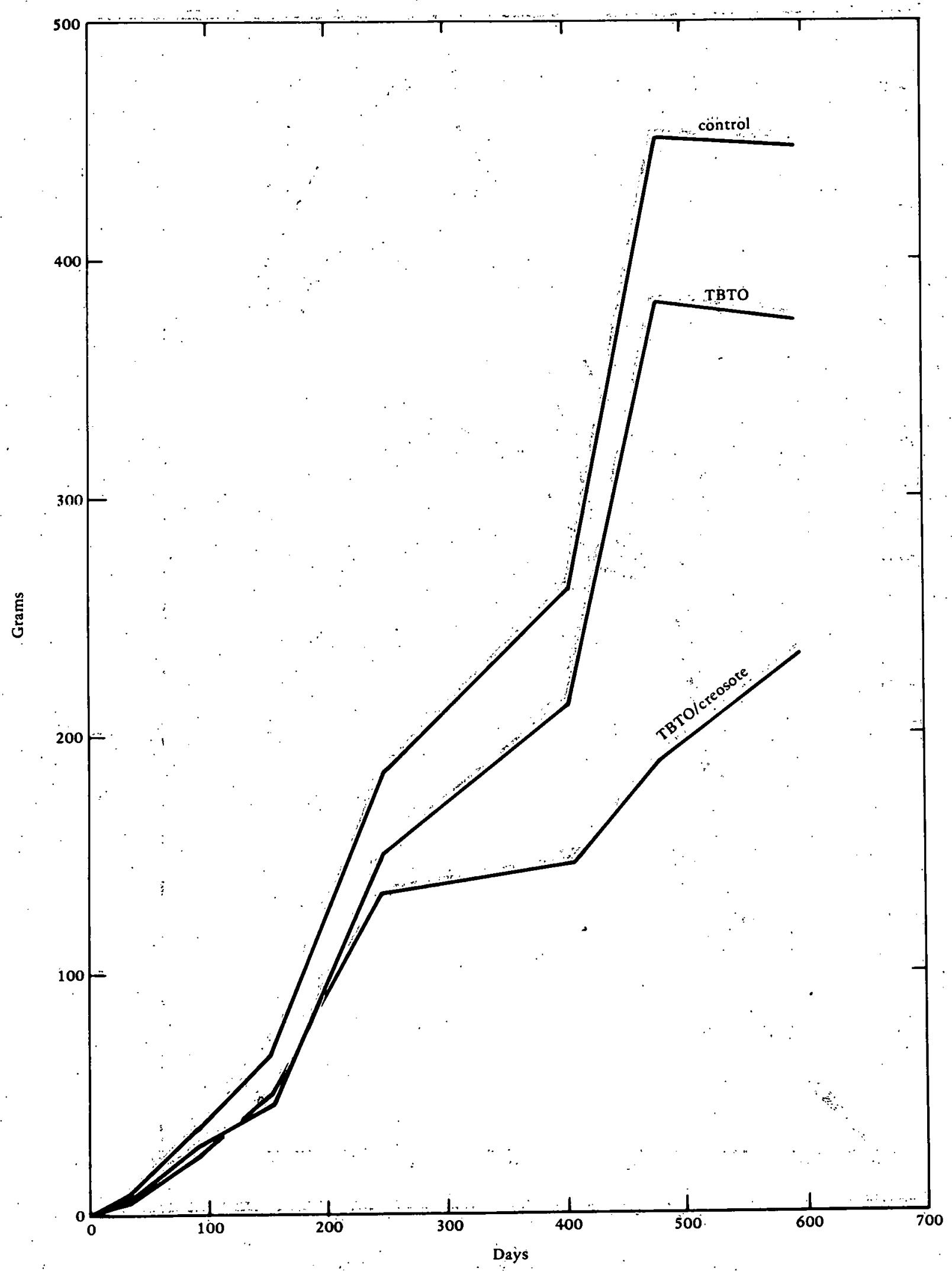

Figure 2. Weight increase, Port Hueneme, set no. $i$. 


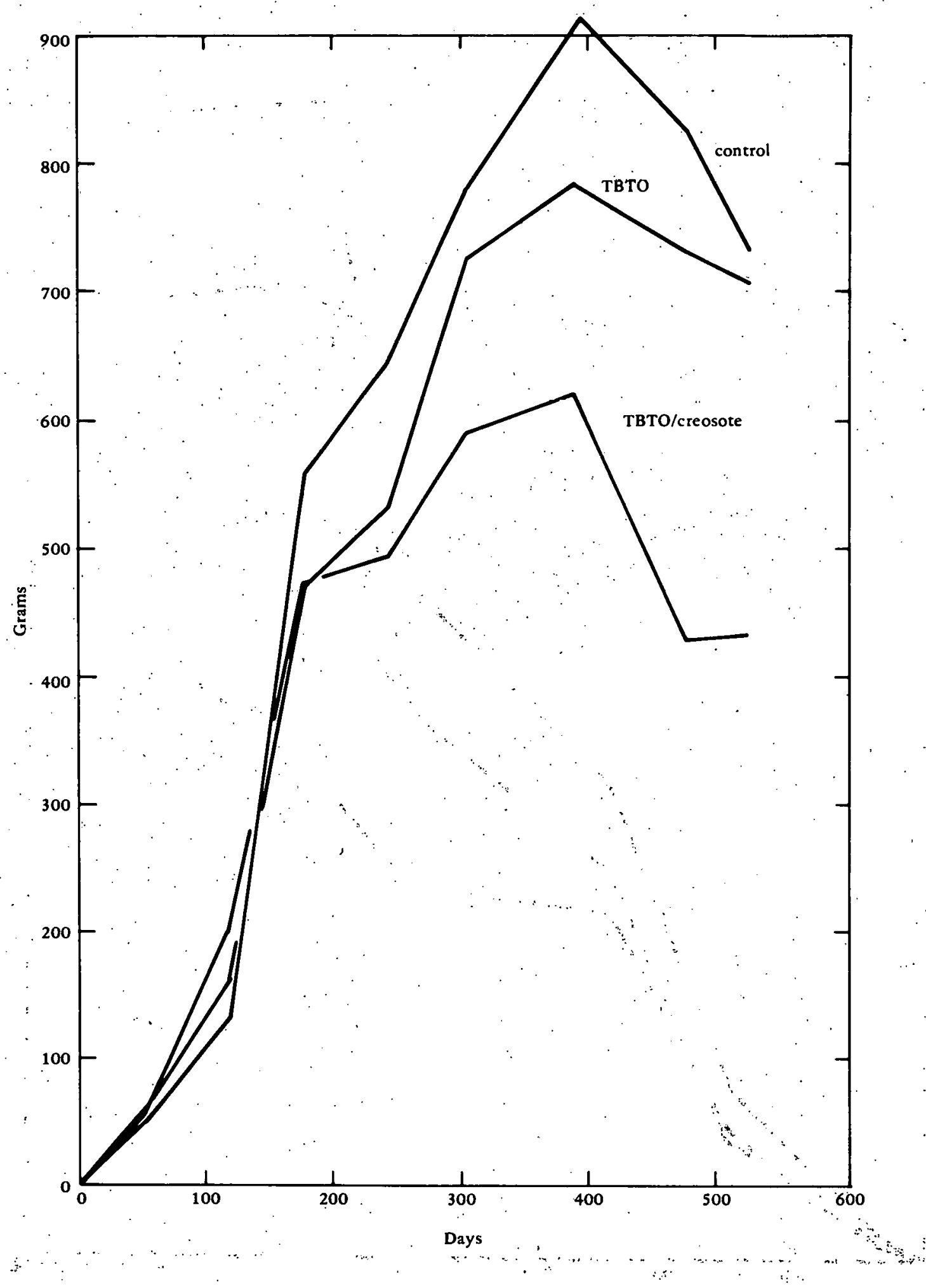

Figure 3. Weight in crease, Key Biscayne, set no. 2.

30 


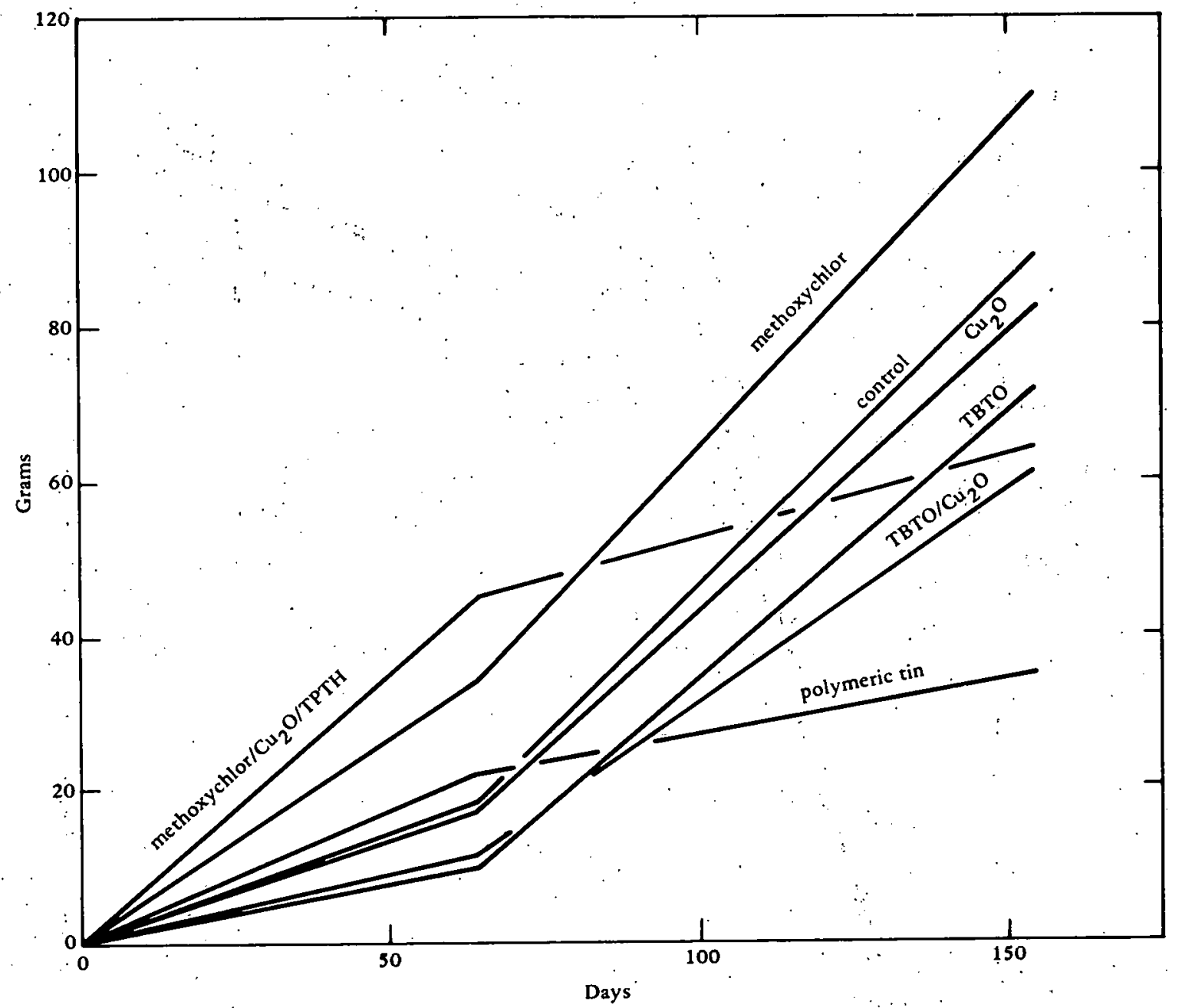

Figure 4. Weight increase, Port Hueneme, set no. 3 and 4. 


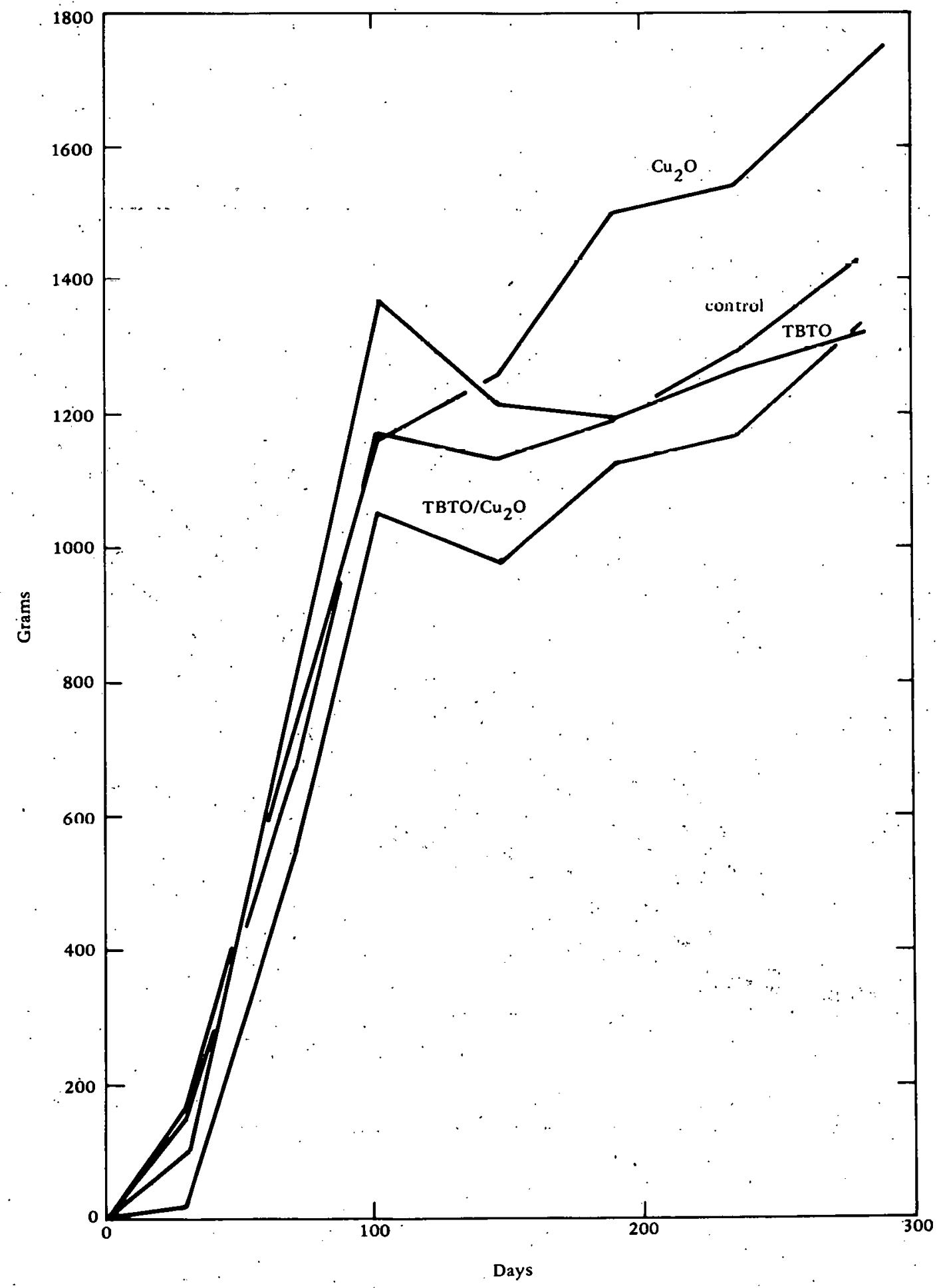

Figure 5. Weight increase, Key Biscayne, set no. 3. 


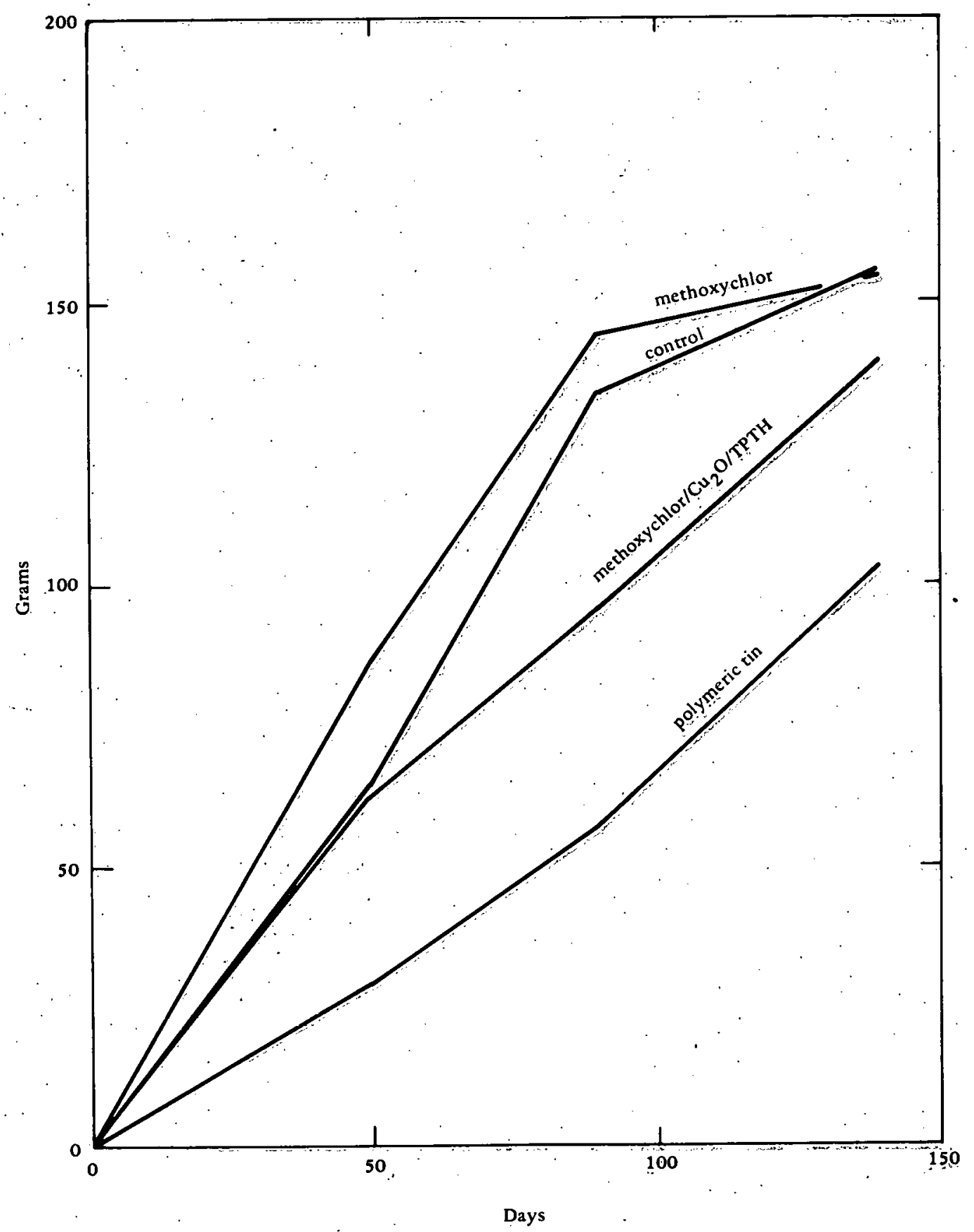

Figure 6. Weight increase, Key Biscayne, set no. 4. 


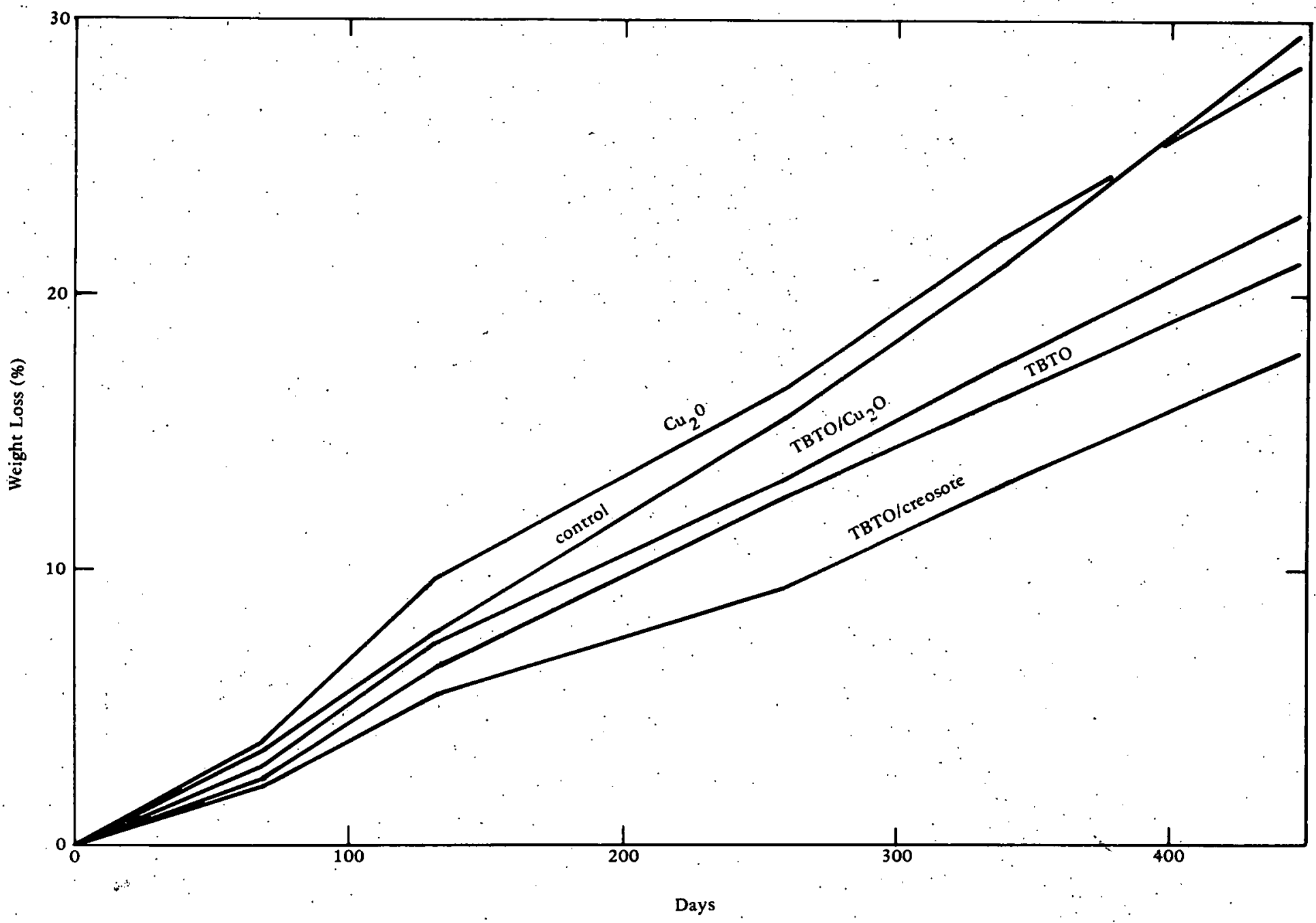

Figure 7. Effect of toxicant on weight loss of simulated reinforcing rod. 
Interna1:

P: H. Benson

J. B. Darby, Jr.

J. D. Ditmars

J. E. Draley (20)

B. R. T. Frost

A. P. Gavin

A. B. Krisciunas
J. J. Roberts

N. F. Sather

A. Thomas

ANL Contract File

ANL Libraries (2)

TIS Files (6)

\section{External:}

DOE-TIC, for distribution per UC-64 (400)

Manager, Chicago Operations and Regional Office, DOE

Chief, Office of Patent Counsel, DOE-CORO.

President, Argonne Universities Association

J. Hilbert Anderson; Sea Solar Power, Inc.

W. H. Avery, Applied Physics Laboratory, Johns Hopkins University

E. Barsness, Westinghouse Electric Corporation; Lester, PA

James 0. Bates, Energy Technology Engineering Center

Kenneth J. Bell, Oklahoma State University

Robert A. Bonewitz, Aluminum Company of America

R. Cohen, US-DOE, Div. of Central Solar Technology

William A. Corpe, Columbia University

R. S. Dalrymple, Reynolds Metals Company, Richmond; VA

G. J. Danek, Anapolis, Maryland

James Denton, TRW Systems and Energy, Redondo Beach, CA

John DePalma, U. S. Naval Oceanographic Office

Stephen Dexter, University of Delaware

Malcom D. Fraser, Intertechnology Corporation

John Gertz, Westinghouse Electric Corporation, Lester, PA

Sigmund Gronich, US-DOE, Div, of Central Solar Technology

P. H. Hadley, Jr., Gibbs \& Cox, Inc.

L. W. Hallanger, Research Corporation, University of Hawaii

William Hartt, Florida Atlantic University

William E. Heronemus, University of Massachusetts

F. K. Hill, Applied Physics Laboratory, Johns Hopkins University

J. F. Jenkins, Civil Engineering Laboratory

E. H. Kinelski, US-DOE, Div. of Central Solar Technology

Robert E. Lacey, Southern Research Institute

F. L. LaQue, Verona, New Jersey

Abrahim Lavi, Carnegi-Mellon University

T. S. Lee, International Nickel Company, Wrightsville Beach, NC

Murray Leitner, Lockheed Missiles and Space Co., Inc., Sunnyvale, CA

Lloyd Lewis, US-DOE, Div, of Central Solar Technology

Brenda Little, NORDA

D. Lott, Naval Coastal Systems Center

Richard N. Lyon, Oak Ridge National Laboratory

Charles W. Mathews, Civil Engineering Laboratory

Frank Mathews, Colorado School of Mines

John W. Michel, Oak Ridge National Laboratory 
Ralph Mitchell, Harvard University

Robert L. Molinari, NOAA/AMOL

R.S.C. Munier, Tracer Marine, Port Everglades, FL

John Nicole, Arthur D. Little, Inc.

Merle Olmsted, General Electric Company, Schenectady, NY

T. B. O'Neill, Civil Engineering Laboratory

Steven Pohlmann, Solar Energy Research Institute

David Price, U. S. National Oceanic \& Atmospheric Administration

W. W. Pritsky, Aluminum Association

J. F. Rynewicz, Lockheed Missiles and Space Co., Inc., Sunnyvale; CA

Donald Sassier, University of Puerto Rico

C. F. Schrieber, Dow Chemical Company, Freeport, TX

B. Shelpuk, Solar Energy Research Institute

William Sheppard, NOAA Data Buoy Office

J. E. Snyder, TRW Systems and Energy, Redondo Beach, CA

Frank Spiehler, NOAA Data Buoy Office

T. J. Summerson, Kaiser Aluminum and Chemical Corp., Pleasanton, CA

R. B. Peel, Chatham, New Jersey

Fred Vukovich, Research Triangle Institute.

J. Paul Walsh, VSE Corporation

E. T. Wanderer, Aluminum Company of America

Ralph L. Webb, Pennsylvania State University

Pat Wilde, University of California at Berkeley

Ralph Williams, PRC Energy Analysis Co.

David C. White, Florida State University

Hank White, Natural Energy Laboratory of Hawaii

36 